Анастасія КОПИТІНА, orcid.org/0000-0002-6083-7385 аспірант, викладач кафедри романської філології та порівняльно-типологічного мовознавства Київського університету імені Бориса Грінченка (Україна, Київ) a.kopytina@kubg.edu.ua

\title{
ЕЛЕКТРОННИЙ ПРОСТІР У СИСТЕМІ КОНЦЕПТУАЛЬНОГО ПОЛЯ «ПРОСТІР»
}

Розвиток електронного простору розглядається у статті як основний актуальний фактор мовних змін. Досліджується вплив екстралінгвального чинника на зміну системи концептуального поля «простір». Стаття містить структуровану система категорії простір, в якій визначається місие середовища «електронний простір». У статті подається визначення концепту «ЕЛЕКТРОННИЙ ПРОСТІР», а також встановлені лексичні зміни, спричинені його появою. Нові лексичні утворення поділяються на три групи за принципом їх семантичної новизни. Як результат у вигляді схеми подається система концептуального поля «простір» з урахуванням змін після включення до нього мікрокониепту «Е-ПРОСТІР».

Ключові слова: електронний простір, мікроконщепт, концептуальне поле «простір», середовище, глобальноінформачійний простір.

Anastasiia KOPYTINA, orcid.org/0000-0002-6083-7385 Phd student, teacher of the Romance language and Typology Department, Borys Grinchenko Kyiv University (Ukraine, Kyiv)a.kopytina@kubg.edu.ua

\section{ELECTRONIC SPACE IN THE SYSTEM OF THE CONCEPTUAL FIELD "SPACE"}

The temporal society is experiencing an era of adapting man to a new environment called "electronic space". The scientific, technical and informational spheres of human activity are regarded as leading permanent producers of new lexemes and concepts in modern society. The electronic space development is considered as the main factor in linguistic changes. The influence of the extralingual factor on the change of the conceptual field "space" system has been researched.

Generalized information on how in the process of evolution and human activity the category of space was structured and split into smaller constituents (environments) is given. The article provides a structured system of space category in which the place of the environment "electronic space" is determined. Sounds, signs, letters, texts are regarded as the "non-electronic information environment" in contrast to "electronic space".

The article contains the definition of the "ELECTRONIC SPACE" concept. Also the article establishes lexical changes caused by the emergence of electronic space. By the method of continuous selection from the Internet discourse, we have obtained lexemes that denote parts of the electronic space, operations with it and indicate its characteristics and are part of the micro-cocncept "E-SPACE" system. In the article they are divided into three groups on the base of novelty. We define electronic space as not limited and as such that will generate new coordinate points and new values for existing tokens.

Two main factors that caused the last changes in the conceptual field "space" are the creation of a new environment "e-space" and the separation of the "outernet" and "Internet" environments from the "e-space". As a result, in the form of a scheme, a system of conceptual field "space" is presented, taking into account the changes after incorporating of the micro-concept "E-SPACE" into it.

Key words: electronic space, lexical-semantic field "space”, environment, microconcept, sociolingual aspect, global information space.

Постановка проблеми. Сучасне суспільство переживає епоху пристосування людини до нового середовища існування під назвою «електронний простір». Технології поліпшуються, кількість власників комп'ютерів та інших гаджетів зростає щодня. Повсякденне життя не обходиться без пошуку чи завантаження інформації за допомогою електронних носіїв. У новому середовищі замість паперових листів на зміну прийшли електронні повідомлення, замість друкованих фото - цифрові і замість друкованих книг та журналів - також електронні. Таким чином, фізичні об'єкти традиційного спілкування (букви, книги тощо) замінюються новими електронними об'єктами. Як фізичні об'єкти існують у фізичному просторі, ці кібероб’єкти існують в «електронному просторі».

Минуле століття відзначилось осягненням космосу та створенням електронного простору. 
За своїми наслідками ці два досягнення є подібними. У першому утворилися нові точки координат, невідомі раніше та фізично недосяжні, які потребували номінації та нового пояснення просторових відношень. У другому випадку внаслідок поширювальної постіндустріальної інформаційної економіки в середині 1990-х рр. утворилась нова комірка у межах наявного простору - електронний простір, простір глобальної мережі Інтернет (Грінхіл, Флетчер, 1996: 181). Саме їх створення спровокувало появу нового середовища існування людини, середовища електронного спілкування, яке швидко замінює більш традиційні способи спілкування і має свої параметри.

Наслідки відкриття електронного простору відзначаються, по-перше, зміною у системі концепту «ПРОСТІР» - ментально-лінгвістичної одиниці, що несе в собі інформацію про просторовий досвід людства. По-друге, задля адаптації до електронного простору відбулася зміна характеру людської комунікації та відносин. Внаслідок таких змін виникає потреба у детальному дослідженні наслідків пристосування мови до електронного простору, які відображаються у мовній картині світу.

Аналіз досліджень. Електронний простір являє собою одиницю вивчення не тільки технічних та інформаційних, але й філософських, соціологічних, психологічних, культурологічних та мовознавчих досліджень, оскільки впливає на всі ці сфери існування людини.

Серед сучасних вітчизняних та зарубіжних досліджень соціальний аспект електронного простору, або кібер-простору, втілено у роботах, присвячених його впливу на соціалізацію людини (О. Богач, С. Бондаренко, В. Плешаков, І. Ейдман, А. Сивалінгам, Ш. Теркл, Дж. Чон), на політично-правову систему (Д. Дубов, О. Манжай, М. Погорецький, П. Вайз, М. Вілсон, М. Постер, Д. Холмс). Серед вітчизняних мовознавців актуальними $€$ питання впливу електронного простору на мовну систему та мовну картину світу. Такі дослідження здійснювали Т. Ілик, Є. Карпіловська, Р. Махчашвілі, Н. Мечковська, С. Чемеркін, О. Ясінська та зарубіжні науковці Дж. Л. Гіббс, Е. Джонсон, Д. Крістал, Л. Макфедієн, Б. Наомі.

Протягом останніх десятиріч зміни у мовній системі розглядалися мовознавцями як внутрішньомовні та зовнішньомовні (І. Кочан, Н. Клименко, С. Карпіловська, Л. Кислюк) або лінгвальні та екстралінгвальні (О. Ахманова, Л. Марчук, С. Семчинський, В. Панфілов, Я. Снісаренко). Нашої уваги потребує саме група екстралінгвальних чинників. За визначенням Л. Архипенко, до екстралінгвальних чинників належать: економічні, суспільно-політичні; культурні та культурно-побутові; наукові; соціально-психологічні фактори (Архипенко, 2005: 5). Тобто до екстралінгвальних факторів ми відносимо зміни в процесі існування людини в суспільстві, її концептуальній картині світу, що провокують собою утворення нових концептів, явищ.

Традиційними екстралінгвальними факторами, що впливали на мовну систему у минулому, були переважно мовні контакти, вперше досліджені у роботах У. Вайнрайха, I. А. Бодуена де Куртене, Г. Пауля, Г. Шухардта, Л. Щерби. Проте в сучасному суспільстві нові мовні контакти зводяться до мінімуму. Постійно продукуючими залишаються науково-технічна та інформаційна сфери діяльності людини, які є провідними у сучасному суспільстві. Перша з них поліпшує старі досягнення та породжує нові відкриття та разом з ними створює нові терміни, поняття, концепти. Друга, інформаційна, займається питанням їх поширення та розповсюдження у світі. Проблему впливу науково-технічного прогресу на систему мови досліджували Н. Волкова, В. Русанівський, Д. Вутон, Б. Нуграард та ін. Саме внаслідок науково-технічного прогресу утворилось нове електронне середовище існування людини - екстралінгвальний чинник з наукової сфери, який є об’єктом нашого дослідження.

Серед досліджень впливу електронного простору на буття людини малодослідженим залишається його мовознавчий аспект. Безпосередньо невирішеною проблемою залишається встановлення актуальних складників, кількісних та якісних змін у концептуальному полі «простір», внаслідок утворення електронного простору.

Мета статті - встановити зміни у системі концептуального поля «простір», спричинених екстралінгвальним чинником - утворенням окремого середовища «електронний простір».

Виклад основного матеріалу. Для вивчення змін у системі концептуального поля «простір» необхідно осягнути соціальні явища, які їм передували i, як наслідок, осягнути зміни, які відбулись у самій категорії простір.

Простір існує незалежно від людини. Людина виконує функцію захоплення простору і розподілення, групування його на середовища свого існування та життєдіяльності. Власне, реальний простір, або «true reality» - це все середовище довкола людини, яке можна сприймати та досліджувати (Махачашвілі, 2016: 5). Це простір, що існував до появи людини і буде існувати у разі іiі зникнення, простір всесвіту, космосу, географіч- 
ний простір, простір невидимий, фізично неосяжний людським оком та умовно розмежований людиною. У процесі діяльності людини «простір» та його складники стали носіями інформації, пасивними агентами комунікативного акту. Як наслідок, власне реальний простір розширив свої межі до так званого «глобально-інформаційного простору» (ГІП), який за визначенням В. Кремень та В. Бикова «є інформаційним відображенням (деякою сукупністю уявних та предметно-інформаційних моделей) загального об'єктного простору» (Кремень, Биков, 2013: 8).

Категорія простору увійшла в нову парадигму сприйняття. Довкола людини утворилося окреме інформаційне середовище залежне від іiі діяльності. Першочергово до нього належали засоби передачі та збереження інформації, відомі ще першим людям: звуки, знаки, букви, тексти які утворюють «позаелектронне інформаційне середовище». На противагу йому утворився «електронний простір», де вже відомі звуки, знаки, букви i тексти отримують нове середовище існування, доступ до якого дають електронні пристрої. За визначенням Оксфордського словника, кібер-простір, або електронний простір (cyberspace) - це відносне середовище, у якому комунікація здійснюється через комп'ютерну мережу $(7,0.5)$.

Підтверджуючи антропоцентричність, людинозалежність інформаційного простору, людина не зупинилась на досягнутому і створила мережу Інтернет. Таким чином «е-простір» розподілився на «інтернет-е-средовище» та «аутернете-середовище». Номінація «аутернет» виникла пізніше, ніж саме позначуване середовище i позначає світ за межами мережі Інтернет (Махачашвілі, 2016:5). «Інтернет-е-середовище» передбачає доступ до інформації за допомогою електронних пристроїв з обов'язковим підключенням до мережі Інтернет. Водночас «аутернет», або «позаінтернет-е-середовище» існує незалежно від всесвітньої мережі та потребує лише самого електронного пристрою для доступу до інформації. На рис. 1.1. зображено, яким чином у процесі еволюції та діяльності людства категорію «простір» було структуровано і роздрібнено до менших складників (середовищ) і де знаходиться категорія «е-простору» у цій структурі. На рис.1.1 можна прослідкувати, як кожне наступне середовище утворювалось довкола знаків, букв чи звуків, носіїв інформації, які утворювали базис і отримували нову інтерпретацію та засіб вираження:

Протягом розмежування простору людину оточують нові поняття та явища, які отримують свою назву. Його внутрішні складники та операції, проведені над ними, також потребують номінацій. Ці нові лексеми на позначення частин електронного простору входять до системи концептуального поля «простір», у якому зберігається вся

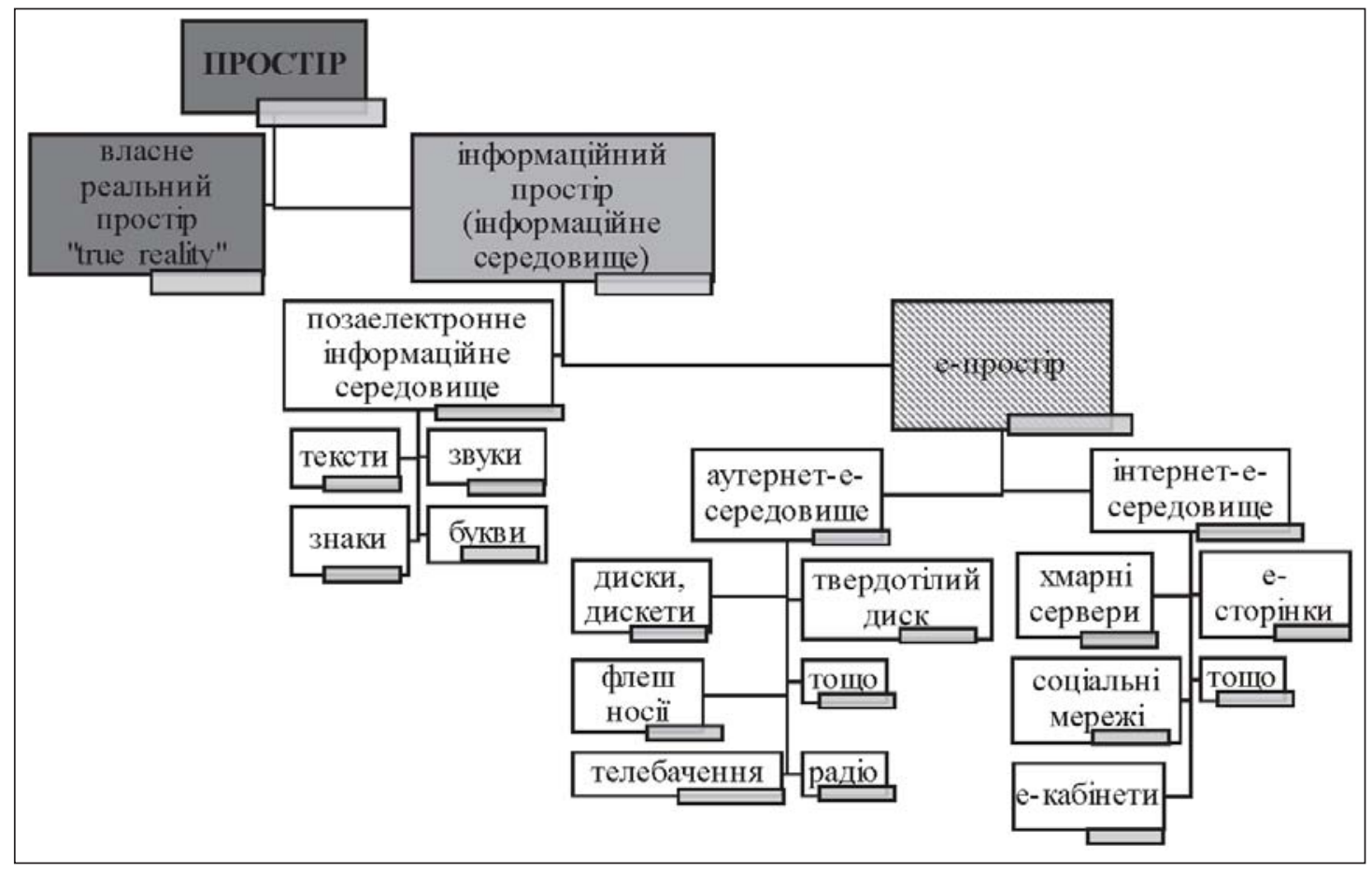

Рис. 1.1. Структура категорії простір 


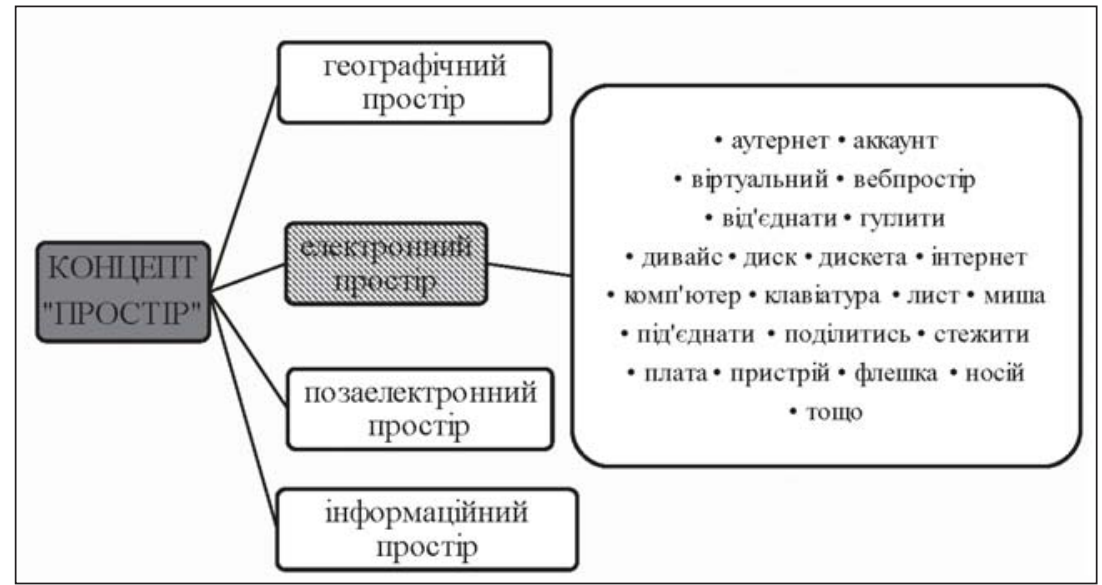

Рис. 1.2. Система концептуального поля «простір» (із зазначенням змін після включення до нього мікроконцепту «Е-ПРОСТІР»)

інформація про категорію простір. До його системи входять також лексеми на позначення дій, пов'язаних з ними (гуглити, підключити, поділитись, стежсти, шукати), ознаки простору (безпечний, відкритий, віртуальний, локальний, перенавантажений, публічний, під'єднаний). Оскільки встановлення меж між периферіями і наповнення секцій в концептуальному полі залежить від координат початково заданих людиною, тобто має антропоцентричний характер, то до його системи можуть входити також індивідуальні лексичні одиниці, пов'язані з електронним простором.

За визначенням М. Кізіль серед способів утворення кіберлексики домінуючими способами $є$ афіксальний спосіб (префікси -cyber, -techno, -tele, e- та суфікси -er -not -iop -ie -ing -ist) та конкретизація значень вже відомих слів (Кізіль, 2016: 146-148). Методом суцільного добирання актуальних новин 3 інтернет-дискурсу ми відібрали лексеми, які позначають частини електронного простору, операції з ним та позначають його характеристики. Серед усіх лексем, утворених як афіксацією, способом конкретизації, так і іншими способами, ми виокремили три групи лексем за принципом їх семантичної новизни:

Абсолютні неологізми, тобто такі лексеми на позначення частин простору чи дій, пов'язаних 3 ним, які не існували раніше і входять до мікроконцепту «Е-ПРОСТІР»: аутернет, акаунт, вебпростір, віртуальний, гуглити, дивайс, диксета, інтернет, комп'ютер, клавіатура, підключити, сайт, сервер, телевізор, флешка тошо:

«Наступного року у світі планують почати реалізацію масштабного за своїм розмахом проекту «Аутернет» (Вголос); «Умови участі в конкурсі РАН зобов'язують виконувати роботи в текстовому редакторі Word 6 зразка 1993 року $i$ надсилати їх на дискетах» (РБК Україна); «На сервер Агентства иивільної авіації Міністерства економіки $і$ стійкого розвитку Грузї здійснили кібератаку 2 травня» (1News); «На найбільшому туристичному ярмарку світу ITB Berlin 2018 показують віртуальний документальний фільм про украӥнський Чорнобиль» (ВВС Україна);

Конкретизовані лексеми на позначення частин простору чи дій, пов'язаних з ним, утворені способом конкретизації значення вже наявних слів: диск, «слайс», «сокет», під'єднати, поділитись, стежити, миша, лист, плата, пристрій тощь:

«Перша миша була великою та громіздкою, в дерев'яному корпусі» (24 News); «Функиія «Поділитись» дає вам змогу поділитися контентом з мобільної версії сайту з іншими користувачами через електронну пошту або соимережі» (BBC Україна); «У середу, 21 березня, в Украӥні було зафіксовано значну кількість спам-розсилок електронних листів» (24 News).

Просторові лексеми, які раніше входили до концептуального поля «простір» і діють у межах мікроконцепту «Е-ПРОСТІР»: безпечний, сітка, мережа, перевантажений, пластмасовий, металевий, мобільний, порт, сучасний, шукати тощь:

«День безпечного Інтернету надає унікальну можсливість для проведення заходів із безпеки в мережі разом зі всім світом...» (Правда ТУТ media group); «3a допомогою сервера SharePoint Server можна по-новому обмінюватися роботою, працювати з іншими користувачами, упорядковувати проекти та групи, а також шукати користувачів й інформацію» (Microsoft); «Bста- 
новлення usb-nopmiв для підзарядки телефонів у вагонах Укрзалізниці» (Електронні петиціï);

Як результат утворення середовища «електронний простір» лексеми, які входять до першої та другої груп мікроконцепту «Е-ПРОСТІР» розширили концептуальне поле «простір». На Рис. 1.2 видно, як у структурі концептуального поля «простір» розмістились абсолютні неологізми та конкретизовані лексеми мікроконцепту «Е-ПРОСТІР»:

Таким чином, основними факторами, що спричинили останні зміни у концептуальному полі «простір», $\epsilon$ :

по-перше, утворення нового середовища «е-простір», який ми визначаємо як секцію «глобально-інформаційного простору», який охоплює лише ту частину простору, що існує в електронному цифровому світі, доступ до якої здійснюється лише за умови наявності технічних засобів;

по-друге, відокремлення у структурі «е-простору» середовища «аутернет» та «Інтернет-простору», які потребують нових просторових визначень і $€$ новим суспільним середовищем існування та спілкування, де продукуються нові лексеми на позначення просторових відношень.

Ці два основні фактори призвели до утворення нових лексичних одиниць у ЛСП «простір». Проте, згадуючи слова американської дослідниці Н. Барон, «вчорашні зміни часто стають нормою сьогодення» (Барон, 2008: 161) та враховуючи темпи науково-технічного прогресу (програми польотів на Марс; проект Hyperloop; VR окуляри; робототехніка тощо) ми визначаємо «е-простір» та «Інтернет-простір» як такі, що мають здатність до нових змін лексичного складу концептуального поля «простір» у майбутньому.

Висновки та пропозиції. У результаті нашого дослідження було встановлено, що продукт науково-технічного прогресу «Е-простір» $є$ середовищем існування людини, доступ до якого здійснюється через фізичні електронні пристрої та носії і має тенденцію до роздроблення на менші середовища. Ми стверджуємо, що поява електронного простору спричинила зміни у концептуальному полі «простір», які виражаються кількісними (утворення нових лексем на позначення нового середовища) та якісними показниками (нові конотативні значення вже наявних раніше слів).

Функціонування середовища «е-простір» спричинило утворення нового мікроконцепту в концептуальному полі «простір». Ми стверджуємо, що концеПт «ЕЛЕКТРОННИЙ ПРОСТІР», або «Е-ПРОСТІР» $\epsilon$ мікроконцептом у структурі макроконцепту «ПРОСТІР», який існує в його системі нарівні 3 мікроконцептами «географічний простір», «інформаційний простір», «поза електронний простір» тощо. Мікроконцепт «Е-ПРОСТІР»- ментально-лінгвістична одиниця мовознавства, що позначає сукупність лексичних одиниць, об'єднаних на основі синонімічності, антонімічності, тематичної єдності, граматичної сполучуваності, на позначення досвіду людини у межах середовища, доступ до якого здійснюється лише через електронні засоби.

Електронний простір не є обмеженим і у майбутньому породжуватиме нові точки координат та нові значення для наявних лексем. Саме тому він $\epsilon$ актуальним екстралінгвальним чинником, соціолінгвальні, лінгвокогнітивні дослідження якого допоможуть у осягненні принципів систематизації лексики, довершенні комп'ютерних словників та перекладачів.

Варто зазначити, що все вищесказане підтверджує динамічність мови і певну хаотичність ії змін, коли подібно «ефекту метелика» кожна найменша зміна в світі провокує зміни в мовній системі.

Результати досліджень можуть слугувати для подальших досліджень інформаційного та електронного простору, соціологічних досліджень простору та когнітивних досліджень просторових лексем. Актуальним вбачаємо діахронічні порівняння неологізмів системи концептуального поля «простір». Перспективним залишається дослідження менших середовищ електронного простору (електронні носії, кібер-спорт, VR окуляри, тощо), які породжують утворення нових просторових лексем.

\section{СПИСОК ВИКОРИСТАНИХ ДЖЕРЕЛ}

1. Архипенко Л. М. Іншомовні лексичні запозичення в українській мові: етапи і ступені адаптації (на матеріалі англіцизмів у пресі кінця XX - початку XXI ст.): автореф. дис. на здобуття наук. ступеня канд. філол. наук: спец. 10.02.01 «Українська мова». Харків, 2005. 20 с. С. 5

2. Кізіль М. А. Структурно-семантичні та соціофункціональні параметри метатерміносистеми англійської мови сфери комп'ютерних технологій: дис. на здобуття наук. ступеня канд. філол. наук: спец. 10.02.04 «Германські мови». Запоріжжя, 2016. 298 с. С. 146-148.

3. Кремень В. Г. Категорії «простір» і «середовище»: особливості модельного подання та освітнього застосування / В.Г. Кремень, В.Ю. Биков. Теорія і практика управління соціальними системами. Харків, 2013. № 2. С. 3-16. URL: http://nbuv.gov.ua/UJRN/Tipuss_2013_2_3 
4. Makhachashvili R.K. Educational e-environment through english vocabulary development. Електронне наукове видання «Відкрите освітнє е-середовище сучасного університету». К., 2016. № 3. C. 161-170. URL: http://openedu.kubg.edu.ua/journal/index.php/openedu/article/viewFile/18/21

5. Baron N. S. Always on: Language in an online and mobile world. New York, NY : Oxford University Press , 2008. pp. 161.

6. Greenhill A., Fletcher G. The Social Construction of Electronic Space. Journal «Social Semiotics». Griffith University, 1996 Volume 6, Issue 2. pp. 179-196

7. Cyberspace: Oxford English Dictionary / edited by J. Simpson and E. Weiner. Clarendon Press, 1989. ISBN 0-19-861186-2. URL: https://en.oxforddictionaries.com/definition/cyberspace (дата звернення: 19.04.2018)

\section{REFERENCES}

1. Arkhipenko L.M. Inshomovni leksichni zapozichennya v ukrayinskiy movi: etapi i stupeni adaptatsiyi (na materiali anglitsizmiv u presi kintsya XX - pochatku XXI st.) [Foreign-language lexical borrowings in the Ukrainian language: stages and stages of adaptation (based on the material of Anglicisms in the press of the end of XX - beginning of the XXI century.)]. Kharkiv, 2005. pp.5 [in Ukrainian]

2. Kizil M.A. Strukturno-semantichni ta sotsiofunktsionalni parametri metaterminosistemi angliyskoyi movi sferi komp'yuternih tehnologiy [Structural-semantic and socio-functional parameters of the metaterninosystem of the English language in the sphere of computer technologies]. Zaporizhzhia, 2016. pp.146-148 [in Ukrainian]

3. Kremin V.G. Kategoriyi «prostir» i «seredovische»: osoblivosti modelnogo podannya ta osvitnogo zastosuvannya [Categories «space» and «environment»: features of model representation and educational application] / V.G. Kremen, V.Yu. Bykov // Theory and practice of social systems management - Kharkiv, 2013. № 2. pp. 3-16. URL: / http://nbuv.gov.ua/UJRN/Tipuss_2013_2_3 [in Ukrainian]

4. Makhachashvili R.K. Ėducational e-environment through English vocabulary development / Rusudan Kirillevna Mahachashvili // Electronic scientific publication «Open Educational E-Environment of the Modern University». Kyiv, 2016. № 3. pp. 161-170. - URL : http://openedu.kubg.edu.ua/journal/index.php/openedu/article/viewFile/18/21

5. Baron N. S. Always on: Language in an online and mobile world. New York, NY : Oxford University Press , 2008. pp. 161

6. Greenhill A., Fletcher G. The Social Construction of Electronic Space./ A. Fletcher, G. Greenhill. Journal «Social Semiotics». Griffith University, 1996. Volume 6, Issue 2. pp. 179-196

7. Cyberspace: Oxford English Dictionary / edited by J.Simpson and E. Weiner. Clarendon Press, 1989. ISBN 0-19-861186-2 URL: https://en.oxforddictionaries.com/definition/cyberspace (дата звернення: 19.04.2018)

Статтю подано до редакиії 11.05.2018 p. 